\title{
PENAMPILAN PRODUKSI AYAM BROILER YANG DIBERI TEPUNG GAMBIR (Uncaria Gambir Roxb) SEBAGAI FEED ADDITIVE DALAM PAKAN
}

\author{
Wa Ode Rosmiati ${ }^{1}$, Natsir Sandiah ${ }^{2}$, dan Rahim Aka $^{2}$ \\ ${ }^{1}$ Mahasiswa Fakultas Peternakan, Universitas Halu Oleo \\ ${ }^{2}$ Dosen Fakultas Peternakan, Universitas Halu Oleo \\ Email : rahim.aka05@gmail.com
}

\begin{abstract}
ABSTRAK
Penggunaan antibiotik sintetis pada ayam broiler dapat menimbulkan efek residu pada manusia sehingga perlu digunakan antibiotik yang bersifat alami seperti gambir. Tujuan penelitian ini adalah untuk mengetahui penampilan produksi ayam broiler yang diberi tepung gambir (Uncaria gambir Roxb) sebagai feed additive dalam pakan. Penelitian ini menggunakan 60 ekor ayam broiler dengan penggunaan tepung gambir sebagai feed additive. Penelitian ini menggunakan rancangan acak lengkap 4 perlakuan dan 3 ulangan. Perlakuan dalam penelitian ini menggunakan penambahan tepung gambir dalam pakan sebanyak $0 \%, 0,5 \%, 1 \%$, dan $1,5 \%$ dari total pemberian pakan. Hasil penelitian ini menunjukan bahwa pemberian tepung gambir dalam pakan ayam broiler tidak menunjukan pengaruh yang nyata $(\mathrm{P}>0,05)$ terhadap konsumsi, namun memberikan pengaruh yang nyata $(\mathrm{P}<0,05)$ terhadap pertambahan bobot badan dan konversi ransum ayam broiler. Kesimpulan dari penelitian ini adalah penggunaan tepung gambir sebagai feed additive dalam pakan ayam broiler dapat diberikan pada level $0,5-1,0 \%$ dari total jumlah pakan.
\end{abstract}

Kata Kunci: broiler, feed additive, tepung gambir, penampilan produksi.

\begin{abstract}
Using of synthetic antibiotics in broiler feed may cause residual effect in human, so it's necessary to use natural antibiotic like as gambier. This study was aimed to discover the production performance of broiler chicken were given gambier flour (Uncaria gambier roxb) as feed additive in feed. This study used 60 bird chickens and used gambier flour as feed addtive. The treatment in this study using the addition of gambier flour $0 \%, 0,5 \%, 1 \%$, and $1,5 \%$ of feed total. The result showed that given of gambier flour in feed of broiler chicken were not significantly different $(\mathrm{P}>0,05)$ to feed consumption, but it's significantly different $(\mathrm{P}<0,05)$ to body weight gain and feed convertion of broiler chicken. Conclution of this study were using of gambier flour as feed additive in feed chicken is better if using level $0,5 \%-1,0 \%$ in feed.
\end{abstract}

Key Word: broiler, feed additive, gambier flour, performance production. 


\section{PENDAHULUAN}

Kebutuhan daging di Indonesia sebagian besar disuplai dari ternak unggas (ayam broiler). Mengoptimalkan produktivitas ayam broiler, selain dipengaruhi oleh faktor genetik juga dipengaruhi oleh faktor pakan, Pakan yang memiliki kandungan protein dan energi yang cukup dapat memacu pertumbuhan ayam broiler. Umumnya peternak menggunakan antibiotik untuk pencegahan atau pengobatan pada ternak ayam broiler, namun demikian penggunaan antibiotik yang berlebihan dapat mengakibatkan efek residu pada daging ayam broiler sehingga dapat berdampak negatif bagi manusia mengkonsumsinya.

Salah satu alternatif untuk mengganti ketergantungan antibiotik ternak ayam broiler dapat dimanfaatkan dengan pemberian tanaman herbal sebagai feed additive dalam pakan ayam broiler. Salah satu tanaman yang dapat dimanfaatkan untuk menganti ketergantungan penggunaan antibiotik pada ayam broiler adalah pemanfaatan tepung gambir.

Usaha mengoptimalkan penampilan produksi adalah dengan pemberian feed additive tepung gambir dalam pakan ayam broiler karena tepung gambir mengandung flavonoid yang telah banyak dimanfaatkan sebagai anti oksidan dan anti bakteri sehingga dapat meningkatkan daya tahan tubuh ternak dan mengurangi angka kematian. Berdasarkan uraian pada latar belakang maka perlu dilakukan penelitian tentang penampilan produksi ayam broiler yang diberi tepung gambir (Uncaria gambir Roxb) sebagai feed additive dalam pakan.

\section{MATERI DAN METODE}

\section{Waktu dan Lokasi}

Penelitian ini Telah dilaksanakan pada Bulan Mei sampai Juni 2016, bertempat di Lab. Unit Ternak Unggas Fakultas Peternakan Universitas Halu Oleo, Kendari.

\section{Metode Penelitian}

Penelitian ini menggunakan ayam broiler sebanyak 60 ekor dan menggunakan ransum BR11 Produksi PT. Charoen Phokpand makasar dengan kadar air 13\%, protein $21-23 \%$, lemak minimal $5 \%$, serat kasar maksimal 7\%, kalsium minimal $0,9 \%$,dan phosphor minimal 0,6\%, air bersih, dan tepung gambir. Kandang yang digunakan sebanyak 12 unit kandang dengan ukuran $1 \mathrm{~m}$ x $1 \mathrm{~m}$ x 0,6 $\mathrm{m}$ dan dilengkapi dengan tempat pakan, tempat minum, serta lampu pijar 15 watt.

Rancangan penelitian yang digunakan adalah Rancangan Acak Lengkap (Completely Randomized Design) dengan 4 (empat) perlakuan dan 3 (tiga) ulangan, masing-masing ulangan terdiri atas 5 (empat) ekor ayam broiler. Susunan perlakuan yang diberikan yaitu :

$\mathrm{P} 0=$ Pakan tanpa tepung gambir $0 \%$

$\mathrm{P} 1=$ Pakan dengan tepung gambir $0,5 \%$

$\mathrm{P} 2=$ Pakan dengan tepung gambir $1 \%$

$\mathrm{P} 3=$ Pakan dengan tepung gambir $1,5 \%$.

Variabel yang diamati dalam penelitian ini adalah konsumsi pakan (gram/ekor), Pertambahan bobot badan (gram/ekor/hari), dan Konversi pakan. Data yang diperoleh dianalisis dengan analisys of variance (ANOVA) dengan diuji $\mathrm{F}$ hitung untuk mengetahui pengaruh perlakuan. Jika perlakuan nyata terhadap perubah maka dilanjutkan dengan uji Beda Nyata Terkecil (BNT) atau Honestly significant Difference (HSD). 


\section{HASIL DAN PEMBAHASAN}

Data hasil penelitian penampilan gambir (uncaria gambir roxb) sebagai feed additive dalam pakan disajikan pada Tabel 1. produksi ayam broiler yang diberi tepung

Tabel 1. Rata-rata Konsumsi Pakan, Pertambahan Bobot Badan, dan Konversi Pakan Ayam Broiler yang Diberi Tepung Gambir (uncaria gambir roxb)

\begin{tabular}{lrrrc}
\hline \multirow{2}{*}{ Variabel } & \multicolumn{3}{c}{ Perlakuan } \\
\cline { 2 - 5 } & P0 & P1 & P2 & P3 \\
\hline $\begin{array}{l}\text { Konsumsi Pakan } \\
\text { (g/ekor) }\end{array}$ & $91,42 \pm 0,64$ & $93,05 \pm 3,00$ & $92,25 \pm 1,37$ & $91,10 \pm 1,15$ \\
PBB (g/ekor/hari) & $55,46 \pm 5,67^{\mathrm{a}}$ & $58,95 \pm 2,03^{\mathrm{b}}$ & $57,94 \pm 1,63^{\mathrm{ab}}$ & $49,09 \pm 0,64^{\mathrm{c}}$ \\
$\begin{array}{l}\text { Konversi pakan } \\
\text { (g/ekor) }\end{array}$ & $1,66 \pm 0,16^{\mathrm{a}}$ & $1,58 \pm 0,10^{\mathrm{a}}$ & $1,59 \pm 0,06^{\mathrm{a}}$ & $1,86 \pm 0,05^{\mathrm{b}}$ \\
\hline
\end{tabular}

Ket: Superscript yang berbeda pada baris yang sama menunjukan berbeda nyata pada taraf $5 \%(\mathrm{P}<0,05)$

\section{Konsumsi Pakan}

Konsumsi pakan merupakan jumlah pakan yang dimakan dalam jumlah waktu tertentu yang akan digunakan oleh ternak untuk memenuhi kebutuhan hidup dan zat makanan lain (Wahju, 2004).

Hasil analisis sidik ragam menunjukan bahwa pemberian feed additive tepung gambir (Uncaria gambir rox) tidak memberikan pengaruh yang nyata $(\mathrm{P}>0,05)$ terhadap tingkat konsumsi ayam broiler. Rata-rata konsumsi Ayam Broiler (Tabel 1.) yang tidak diberi feed additive tepung gambir (Uncaria gambir rox) (P0) adalah 91,42 $\pm 0,64$ gram/ekor/hari, sedangkan konsumsi rata-rata Ayam Broiler dengan pemberian feed additive tepung gambir adalah berkisar $91,10 \pm 1,15$ sampai $93,05 \pm 3,00$ gram/ekor/hari.

Hasil penelitian ini tidak berbeda jauh dengan hasil penelitian Negoro (2013) yang melakukan penelitian tentang pengaruh penggunaan tepung kemangi dalam pakan ayam broiler selama 30 hari pemeliharaan yaitu bahwa rata-rata konsumsi ayam broiler dengan penambahan tepung kemangi yaitu 94,82gram/ekor/hari. Hasil yang sama juga diperoleh Ardianto (2013) yang melakukan penelitian tentang pengaruh penambahan probiotik pada air minum ayam broiler memperoleh hasil bahwa rata-rata konsumsi pakan ayam broiler pada penelitiannya berkisar antara 88,88 - 92,21 gram/ekor/hari.

\section{Pertambahan Bobot Badan}

Pertambahan bobot badan merupakan kenaikan bobot badan yang dicapai seekor ternak selama periode tertentu. Pertambahan bobot badan diperoleh dengan pengukuran kenaikan bobot badan dengan melakukan penimbangan berulang dengan waktu tertentu (Situmorang dkk., 2013).

Hasil analisis sidik ragam menunjukan bahwa pemberian feed additive tepung gambir (Uncaria gambir rox) berpengaruh nyata $(\mathrm{P}<0,05) \quad$ dalam meningkatkan pertambahan bobot badan (PBB) ayam broiler. Pertambahan bobot badan rata-rata. Ayam broiler (Tabel 1) yang tidak diberi feed additive tepung gambir (Uncaria gambir rox) adalah 55,46 $\pm 5,67$ gram/ekor/hari (P0), sedangkan pertambahan bobot badan Ayam Broiler dengan pemberian feed additive tepung gambir adalah berkisar $49,09 \pm 0,64 \quad$ gram/ekor/hari sampai $58,95 \pm 2,03$ gram/ekor/hari.

Hasil penelitiaan ini lebih tinggi dibandingkan Negoro (2013) yang meneliti tentang pengaruh pemberian pakan dengan penambahan tepung kemangi pada ayam 
broiler selama 30 hari pemeliharaan menunjukan bahwa pertambahan bobot badan (PBB) ayam dengan konsentrasi tepung kemangi 2\%, 4\%, dan $6 \%$ masingmasing yaitu 47,18 gram/ekor/hari, 49,68 gram/ekor/hari, 48,58 gram/ekor/hari dan 46,23 gram/ekor/hari.

Berdasarkan hasil uji tersebut dapat dikatakan bahwa penambahan $0,5 \%$ dan $1 \%$ tepung gambir dapat meningkatkan PBB ayam broiler, namun menurun kembali seiring dengan meningkatnya level pemberian tepung gambir. Hal tersebut diduga karena semakin tinggi pemberian tepung gambir dalam pakan, maka palatibilitas pakan akan menurun sehingga keinginan ayam untuk makan menurun. Konsumsi pakan yang rendah akan berdampak pada rendahnya pertambahan bobot badan ayam. Uzer dkk., (2013) menjelaskan bahwa pertambahan bobot badan sangat berkaitan dengan pakan, baik kuantitas maupun kualitas pakan. Dalam hal kuantitas berkaitan dengan konsumsi pakan dimana apabila konsumsi pakan terganggu maka akan mengganggu pertumbuhan.

\section{Konversi Pakan}

Konversi pakan merupakan salah satu standar dalam berproduksi yang dapat digunakan sebagai pedoman untuk efisiensi penggunaan pakan oleh ternak. Hasil analisis statistik menggunakan sidik ragam menunjukan bahwa pemberian feed additive tepung gambir (Uncaria gambir rox) berpengaruh nyata $(\mathrm{P}<0,05)$ dalam menurunkan konversi pakan ayam broiler.

Rata-rata konversi pakan ayam Broiler (Tabel 1) yang tidak diberi feed additive tepung gambir (Uncaria gambir rox) adalah 1,66 $\pm 0,16(\mathrm{P} 0)$, sedangkan konversi pakan rata-rata Ayam Broiler dengan pemberian feed additive tepung gambir $0,5 \%$ (P1) yaitu 1,58 $\pm 0,10$, pemberian tepung

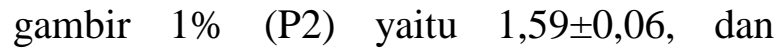
pemberian tepung gambir $1,5 \%$ (P3) yaitu $1,86 \pm 0,05$. Hasil penelitiaan ini lebih rendah dibandingkan dengan hasil penelitian
Muharlien dkk. (2010) bahwa angka konversi ayam pedaging yang dipotong umur 4 minggu adalah 1,76. Dan Negoro (2013) yang meneliti tentang pengaruh pemberian pakan dengan penambahan tepung kemangi pada ayam broiler selama 30 hari pemeliharaan menunjukan bahwa konversi pakan ayam pedaging dengan konsentrasi tepung kemangi $0 \%, 2 \%, 4 \%$, dan $6 \%$ masing-masing yaitu 2,03, 1,91, 1,95, dan 2,06 .

Berdasarkan data hasil penelitian ini, dapat dikatakan bahwa penambahan $0,5 \%$ tepung gambir dapat menurunkan angka konversi pakan, namun seiring dengan meningkatnya level pemberian tepung gambir dapat meningkatkan konversi pakan. Hal ini menunjukan bahwa efektifitas tepung gambir dalam memperbaiki nilai konversi pakan ayam broiler hanya pada level $0,5 \%$ dan $1 \%$.

Konversi pakan mencerminkan keberhasilan dalam memilih atau menyusun pakan yang berkualitas. Angka konversi pakan minimal dipengaruhi oleh tiga faktor yaitu kualitas pakan, teknik pemberian pakan dan angka mortalitas (Amrullah, 2004).

\section{KESIMPULAN}

Pemberian feed additive tepung gambir (Uncaria gambir rox) secara statistik signifkan $(\mathrm{P}<0,05)$ dalam meningkatkan pertambahan bobot badan (PBB) dan menurunkan konversi pakan ayam broiler, namun tidak menunjukan pengaruh yang nyata terhadap tingkat konsumsi pakan ayam broiler.

\section{DAFTAR PUSTAKA}

Amrullah, I. K. 2004. Nutrisi ayam aroiler. Cetakan Ketiga. Lembaga Gunung Budi. Bogor.

Ardianto E., 2013. Pengaruh Penambahan Probiotik dalam Air Minum terhadap 
Penampilan Produksi Ayam

Pedaging. Skripsi. Fakultas

Peternakan, Universitas Brawijaya.

Malang.

Muharlien, Achmanu dan R.Rachmawati. 2011. Meningkatkan Produksi Ayam Pedaging Melalui Pengaturan Proporsi Sekam, Pasir Dan Kapur Sebagai Litter. Jurnal Ilmu Ternak Tropika. Universitas Brawijaya. Malang.

Negoro, A. S. P. 2013. Pengaruh Penggunaan Tepung Kemangi dalam Pakan terhadap Penampilan Produksi Ayam Pedaging. Skripsi. Fakultas Peternakan, Universitas Brawijaya. Malang.

Sitomorang, L. D. Mahfudz, dan U. Atmomarsono. 2013. Pengaruh Pemberian Tepung rumput Laut (gracilaria verrucosa) Dalam Ransum Terhadap Efisien Penggunaan Protein Ayam Broiler. Animal Agricultural Journa, 2(1):4956.

Uzer, F., I. Ning, dan Roesdiyanto. 2013. Penggunaan Pakan Fungsional Dalam Ransum Terhadap Konsumsi Pakan dan Pertambahan Bobot Badan Ayam Broiler. Jurnal Ilmiah Peternakan, 1(1):282-288

Wahju, J. 2004. Ilmu Nutrisi Unggas. Cetakan ke-5. Gadjah Mada University Press. Yogyakarta. 